\title{
Tissue factor as the main activator of the coagulation system during cardiopulmonary bypass
}

F. De Somer, ECCPa

Y. Van Belleghem, $M D^{\mathrm{a}}$

F. Caes, MD

K. François, $M D^{a}$

H. Van Overbeke, $M D^{\mathrm{a}}$

J. Arnout, $\mathrm{MD}, \mathrm{PhD}^{\mathrm{b}}$

Y. Taeymans, MD, $\mathrm{PhD}^{\mathrm{a}}$

G. Van Nooten, MD, $\mathrm{PhD}^{\mathrm{a}}$
From the Heart Centre, ${ }^{a}$ University Hospital Gent, and Centre for Molecular and Vascular Biology, ${ }^{\text {b }}$ University Leuven, Belgium.

Received for publication Sept 7, 2001; accepted for publication Sept 7, 2001

Address for reprints: G. Van Nooten, MD, $\mathrm{PhD}$, University Hospital Gent, Centre for Cardiac Surgery 51E-K12, De Pintelaan 185, B-9000 Gent, Belgium (E-mail: Guido.VanNooten@rug.ac.be).

J Thorac Cardiovasc Surg 2002;123:951-8

Copyright () 2002 by The American Association for Thoracic Surgery

0022-5223/2002 \$35.00+0 $\quad \mathbf{1 2 / 1 / 1 2 0 3 3 4}$

doi: $10.1067 / \mathrm{mtc} .2002 .120334$
Objective: This study investigates the influence of foreign material and blood aspirated from nonvascular structures on activation of coagulation, hemolysis, and blood loss.

Methods: The series comprises 3 randomized groups (groups $\mathrm{C}, \mathrm{S}$, and $\mathrm{S}+\mathrm{P}$ ) of 10 patients undergoing routine coronary artery bypass grafting with cardiopulmonary bypass. In group $\mathrm{C}$, the control group, all aspirated blood was returned into the circulation. In group $\mathrm{S}$ suction blood was discarded, whereas group $\mathrm{S}+\mathrm{P}$ was identical to group $S$, with surfaces coated with phosphorylcholine. Plasma concentrations of $\beta$-thromboglobulin, thrombin generation, haptoglobin, and free hemoglobin, as well as blood loss, were measured.

Results: A steady increase in free plasma hemoglobin, as well as an increased generation of thrombin, was noticed in group C. Moreover, a close correlation ( $r=$ 0.916) between the generation of thrombin and its inhibition (thrombin-antithrombin complexes) was observed. Platelets were clearly activated in group $\mathrm{C}$ and, to a lesser extent, in group $\mathrm{S}$. In contrast, platelet activation in group $\mathrm{S}+\mathrm{P}$ was negligible, resulting in a $30 \%$ decrease in blood loss $(P=.05)$.

Conclusions: Aspirated blood contaminated by tissue contact is the most important activator of the coagulation system and the principal cause of hemolysis during cardiopulmonary bypass. Contact with a foreign surface is not a main variable in the procoagulant effect of bypass. Mimicking the outer cell membrane structure resulted in decreased platelet activation and decreased blood loss.

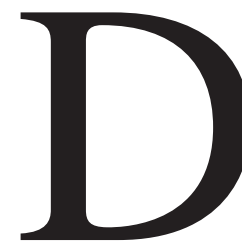

uring cardiopulmonary bypass (CPB), blood is diverted into an extracorporeal circulation. Those foreign surfaces exert a strong procoagulant effect. ${ }^{1}$ Over the years, many improvements have been made to the components of the CPB circuit. Heparin coating and, more recently, phosphorylcholine coating definitively reduce inflammatory response. ${ }^{2,3}$ The characteristic feature of biologic membranes is their functional and compositional lipid asymmetry, which has been described in several cell types. It is thought to stem from the requirement of biologic membranes to have asymmetric protein distributions across the bilayer. In all of the cells for which lipid compositional asymmetry has been described, negatively charged phospholipids are found predominantly on the inner cytoplasmatic side of the membrane, whereas the neutral zwitterionic phosphorylcholine containing antithrombotic lipids predominate in the outer membrane leaflet. Negatively charged phospholipids are thrombogenic. This membrane asymmetry may serve the biologic 
TABLE 1. Demographic data and operative details of the studied groups*

\begin{tabular}{lccc}
\hline Clinical parameter & Group C $(\mathbf{n}=\mathbf{1 0})$, mean $\mathbf{\pm}$ SD & Group S $(\mathbf{n}=\mathbf{1 0})$, mean \pm SD & Group S + P $(\mathbf{n}=\mathbf{1 0})$, mean \pm SD \\
\hline Age $(\mathrm{y})$ & $62 \pm 8$ & $67 \pm 11$ & $64 \pm 10$ \\
Female/male sex & $4 / 6$ & $1 / 9$ & $0 / 10$ \\
Weight $(\mathrm{kg})$ & $81 \pm 14$ & $77 \pm 9$ & $83 \pm 13$ \\
No. of distal anastomoses & $3.9 \pm 0.9$ & $3.5 \pm 0.7$ & $3.8 \pm 0.6$ \\
Extracorporeal time (min) & $91 \pm 26$ & $80 \pm 15$ & $78 \pm 16$ \\
Aortic crossclamp time (min) & $50 \pm 16$ & $39 \pm 7$ & $43 \pm 10$
\end{tabular}

*All parameters were analyzed with the unpaired Student $t$ test and showed no significant differences among the 3 study groups.

purpose in the maintenance of the delicate balance between hemostasis and thrombosis. However, reduction in activation of the coagulation cascade and cell trauma is not conclusive. ${ }^{3}$ This might be related to the fact that, in most clinical studies, aspirated blood, which is recognized as one of the most injurious components, ${ }^{4}$ is still reused. The purpose of this study is to investigate the contribution of aspirated blood versus foreign material in the activation of the coagulation cascade and cell trauma.

\section{Patients and Methods}

\section{Patients}

Thirty patients were prospectively randomized into 1 of 3 groups. All patients were subjected to elective coronary artery bypass grafting. The sole exclusion criterion was an ejection fraction of less than $40 \%$. There were no statistical differences in demographics and operative data between groups (Table 1). The medical ethical committee of the hospital approved the study, and written informed consent was obtained from all patients.

In the control group (group $\mathrm{C} ; \mathrm{n}=10$ ) $\mathrm{CPB}$ was performed in a standard fashion, with recuperation of all suction blood into the circulation. In the second group (group $\mathrm{S} ; \mathrm{n}=10$ ) the same circuit was used as in the control group, but aspirated blood collected from the mediastinal cavities, pleural cavities, or both, was discarded. The third group (group $\mathrm{S}+\mathrm{P} ; \mathrm{n}=10$ ) was identical to group 2, except for the coating of all foreign material with phosphorylcholine.

\section{Operative Techniques}

Before cannulation, porcine heparin (300 IU/kg; Roche Pharmaceuticals, Mannheim, Germany) was injected. Activated coagulation time (kaolin ACT; Medtronic HemoTec, Inc, Englewood, Colo) was kept above 400 seconds throughout CPB. CPB consisted of a custom tubing pack made of polyvinyl chloride, an arterial filter, a membrane oxygenator, and an open venous reservoir with separated cardiotomy reservoir (Dideco, Mirandola, Italy). Circuits were identical in the different groups, with the exception of group $\mathrm{S}+\mathrm{P}$, in which all surfaces in contact with blood were coated with phosphorylcholine. The heart-lung machine (COBE Cardiovascular, Inc, Arvada, Colo) was primed with a mixture of gelatin solution (Pasteur Merieux, Lyon, France), mannitol (Baxter Healthcare Corporation, Deerfield, Ill), 2 million KIU of aprotinin (Bayer AG, Leverkusen, Germany), and 5000 IU of heparin (Roche, Brussels, Belgium). Total priming volume was $1300 \mathrm{~mL}$. Esophageal temperature was lowered to $28^{\circ} \mathrm{C}$. If possi- ble, autologous blood was removed after induction, aiming at a hematocrit level of 25\% during CPB. During aortic crossclamping, the aortic root was vented with a pressure-controlled roller pump. Myocardial preservation during aortic crossclamping was obtained with approximately $800 \mathrm{~mL}(600-900 \mathrm{~mL})$ of crystalloid, antegrade, modified St Thomas' Hospital cardioplegic solution.

\section{Blood Sampling}

Blood samples were taken after induction, at 15 minutes of $\mathrm{CPB}$, 5 minutes after release of the aortic crossclamp, at the end of CPB, 20 minutes after CPB, and on postoperative days 1 and 2. Total blood loss was documented at 4, 8, and 12 hours postoperatively.

\section{Laboratory Assays}

Serum concentrations of free hemoglobin and haptoglobin were determined as markers of hemolysis by using immunonephelometry $^{5}$ on a BN nephelometer (Behringwerke AG, Marburg, Germany) and expressed according to Instructional Faculty Consortium Committee standards. ${ }^{6}$

The prothrombin fragment $(\mathrm{F} 1+2)$, split off during conversion of prothrombin to thrombin, was measured on citrated plasma by using a quantitative enzyme-linked immunosorbent assay (ELISA; Enzygnost F1+2 micro, Behring Diagnostics GmbH, Frankfurt, Germany). The capture antibodies in this sandwich ELISA are highly specific polyclonal antibodies raised in rabbits against a synthetic peptide from the negatively charged region of the $\mathrm{F} 1+2$ fragment. Peroxidase-conjugated rabbit anti-human prothrombin antibodies are used as the tagging antibody. The normal level, determined in 24 healthy volunteers, is $1.16 \pm 0.39 \mathrm{nmol} / \mathrm{L}$ (range, 0.5-2.6 nmol/L; median, $1.1 \mathrm{nmol} / \mathrm{L})$.

Thrombin-antithrombin complexes (TATs), reflecting thrombin generation followed by inhibition by antithrombin, were determined on citrated plasma by means of ELISA (Enzygnost TAT micro; Behring Diagnostics $\mathrm{GmbH}$ ), according to the manufacturer's instructions. This ELISA uses a polyclonal antibody specific for neoantigenic determinants on thrombin as the capture antibody and peroxidase-labeled polyclonal rabbit anti-human antithrombin III as the tag antibody. The normal TAT level, determined in 24 healthy volunteers, is $4.07 \pm 2.33 \mathrm{ng} / \mathrm{mL}$ (range, $2-14.9 \mathrm{ng} / \mathrm{mL}$; median, $3.4 \mathrm{ng} / \mathrm{mL}$ ).

$\beta$-Thromboglobulin $(\beta$-TG) released from $\alpha$-granules at platelet activation was recorded with commercially available ELISA testing (Asserachrom $\beta$-TG; Diagnostica Stago, Parsippany, NJ). Normal values determined in 40 healthy donors ranged from 15 to $42 \mathrm{IU} / \mathrm{mL}$ (mean, $24.4 \mathrm{IU} / \mathrm{mL}$ ). 

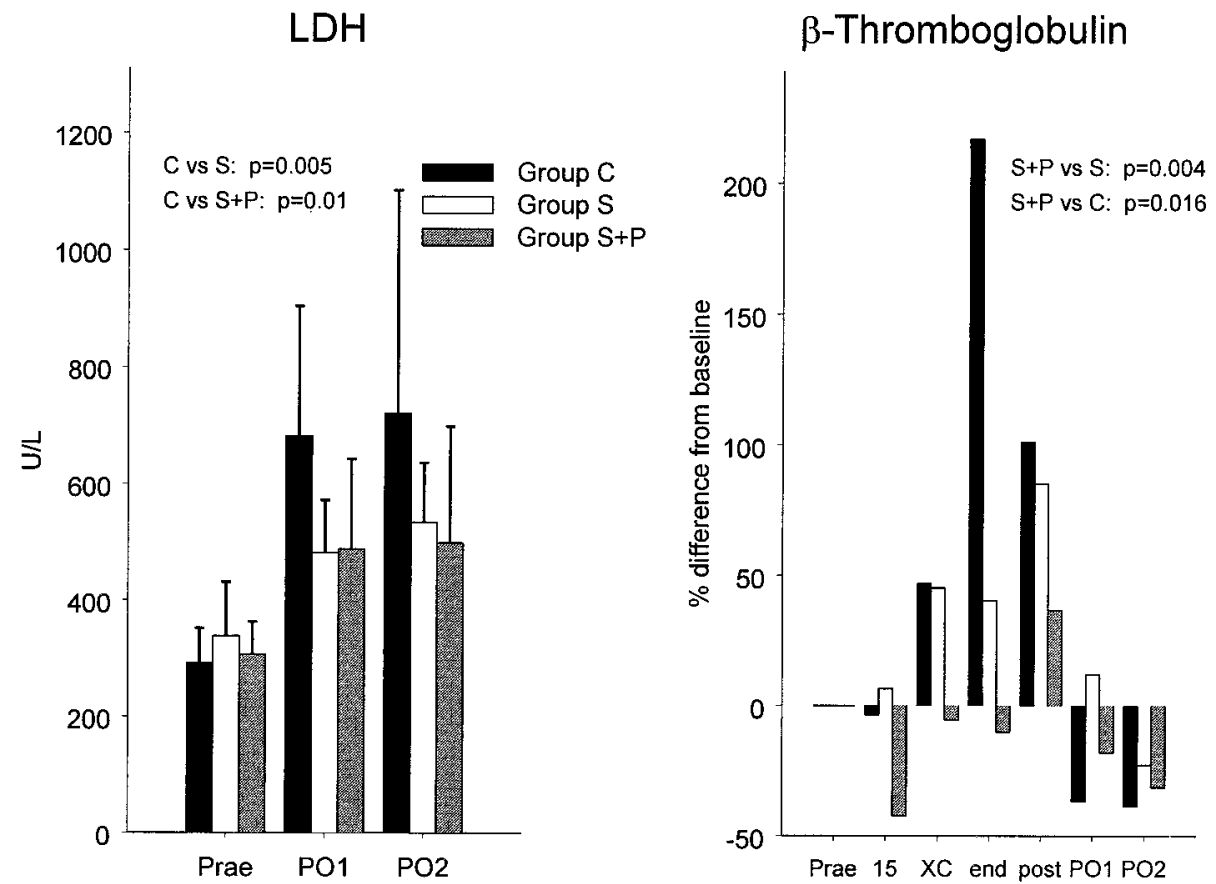

Figure 1. LDH and $\beta$-TB levels. Pre, Blood samples taken after induction; P01 and P02, blood samples taken on postoperative days 1 and 2; $X C$, blood samples taken after release of the aortic crossclamp; post, blood samples taken 20 minutes after CPB.

\section{Statistics}

The overall differences among the 3 groups were analyzed with a Kruskal-Wallis test. The comparison between each individual group was done with a Mann-Whitney test corrected for repeated comparisons. The sample points were related to the progress of the operation and differed in each patient. Comparisons at each sample point were therefore not considered relevant. Hence, the values were treated individually for each patient, calculating the surface under the curve representing the total release during CPB.

The correlation between the generation of thrombin $(\mathrm{F} 1+2)$ and its inhibition (TAT) was calculated with a Spearman $R$ test.

\section{Results}

\section{Coagulation}

Lactic dehydrogenase. Lactic dehydrogenase (LDH) levels increased in all groups on postoperative days 1 and 2 compared with baseline values (Figure 1). Mean total LDH release was $296,318 \pm 137,924 \mathrm{U} / \mathrm{L}$ per procedure in group $\mathrm{C}, 112,170 \pm 75,153 \mathrm{U} / \mathrm{L}$ per procedure in group $\mathrm{S}(P=$ $.005)$, and $136,212 \pm 91,602 \mathrm{U} / \mathrm{L}$ per procedure in group $\mathrm{S}+\mathrm{P}(P=.01)$.

$\boldsymbol{\beta}$-Thromboglobulin. The concentration of $\beta$-TG remained stable during $\mathrm{CPB}$ in group $\mathrm{S}+\mathrm{P}$, whereas an increase over time was observed in groups $\mathrm{S}$ and $\mathrm{C}$ (Figure 1). In all groups an increase of baseline values was noted at 20 minutes after CPB. Mean total release of $\beta$-TG during CPB was $3790 \pm 4103 \mathrm{IU} / \mathrm{mL}$ per $\mathrm{CPB}$ in the $\mathrm{S}+\mathrm{P}$ group,
$18,870 \pm 20,479 \mathrm{IU} / \mathrm{mL}$ per CPB in group $\mathrm{C}(P=.016)$, and $8040 \pm 3986 \mathrm{IU} / \mathrm{mL}$ per $\mathrm{CPB}$ in group $\mathrm{S}(P=.004)$.

Prothrombin fragment $1+2$. In the control group an important increase in $\mathrm{F} 1+2$ levels was noted during $\mathrm{CPB}$ (Figure 2) from a mean baseline value of $1.9 \pm 1.8$ to $5.0 \pm$ $3.0 \mu \mathrm{g} / \mathrm{L}$ at the end of $\mathrm{CPB}$, which further increased to $5.4 \pm 2.3 \mu \mathrm{g} / \mathrm{L}$ at 20 minutes after $\mathrm{CPB}$. In groups $\mathrm{S}$ and $\mathrm{S}+\mathrm{P}$ the values remained stable during and after $\mathrm{CPB}$. Mean total F1 +2 levels during CPB were 20,594 $\pm 21,733$ $\mu \mathrm{g} / \mathrm{L}$ per CPB in group $\mathrm{C}, 2534 \pm 2365 \mu \mathrm{g} / \mathrm{L}$ per CPB in group $\mathrm{S}(P=.001)$, and $2197 \pm 2095 \mu \mathrm{g} / \mathrm{L}$ per $\mathrm{CPB}$ in group $\mathrm{S}+\mathrm{P}(P=.001)$.

Thrombin-antithrombin complex. Mean values of TAT complex decreased slightly in groups $\mathrm{S}$ and $\mathrm{S}+\mathrm{P}$, from $25.3 \pm 42.7 \mathrm{nmol} / \mathrm{L}$ and $24.6 \pm 21.9 \mathrm{nmol} / \mathrm{L}$ to $8.6 \pm 8.1$ $\mathrm{nmol} / \mathrm{L}$ and $7.3 \pm 2.2 \mathrm{nmol} / \mathrm{L}$ at 15 minutes of bypass, respectively (Figure 2). Subsequently, the values remained stable during CPB and returned to baseline values at 20 minutes after $\mathrm{CPB}$. This is in opposition to group $\mathrm{C}$, in which the mean baseline value of $56.9 \pm 85.8 \mathrm{nmol} / \mathrm{L}$, after a first decrease to $30.8 \pm 22.4 \mathrm{nmol} / \mathrm{L}$, started to increase to a value of $128.0 \pm 96.1 \mathrm{nmol} / \mathrm{L}$ at the end of CPB. Mean total generation of TAT during CPB was $62,926 \pm 81,907$ $\mathrm{nmol} / \mathrm{L}$ per CPB in group $\mathrm{C}$ versus $4009 \pm 2958 \mathrm{nmol} / \mathrm{L}$ per $\mathrm{CPB}$ in group $\mathrm{S}(P=.001)$ and $3925 \pm 1593 \mathrm{nmol} / \mathrm{L}$ per $\mathrm{CPB}$ in group $\mathrm{S}+\mathrm{P}(P=.001)$. Moreover, close correlation 

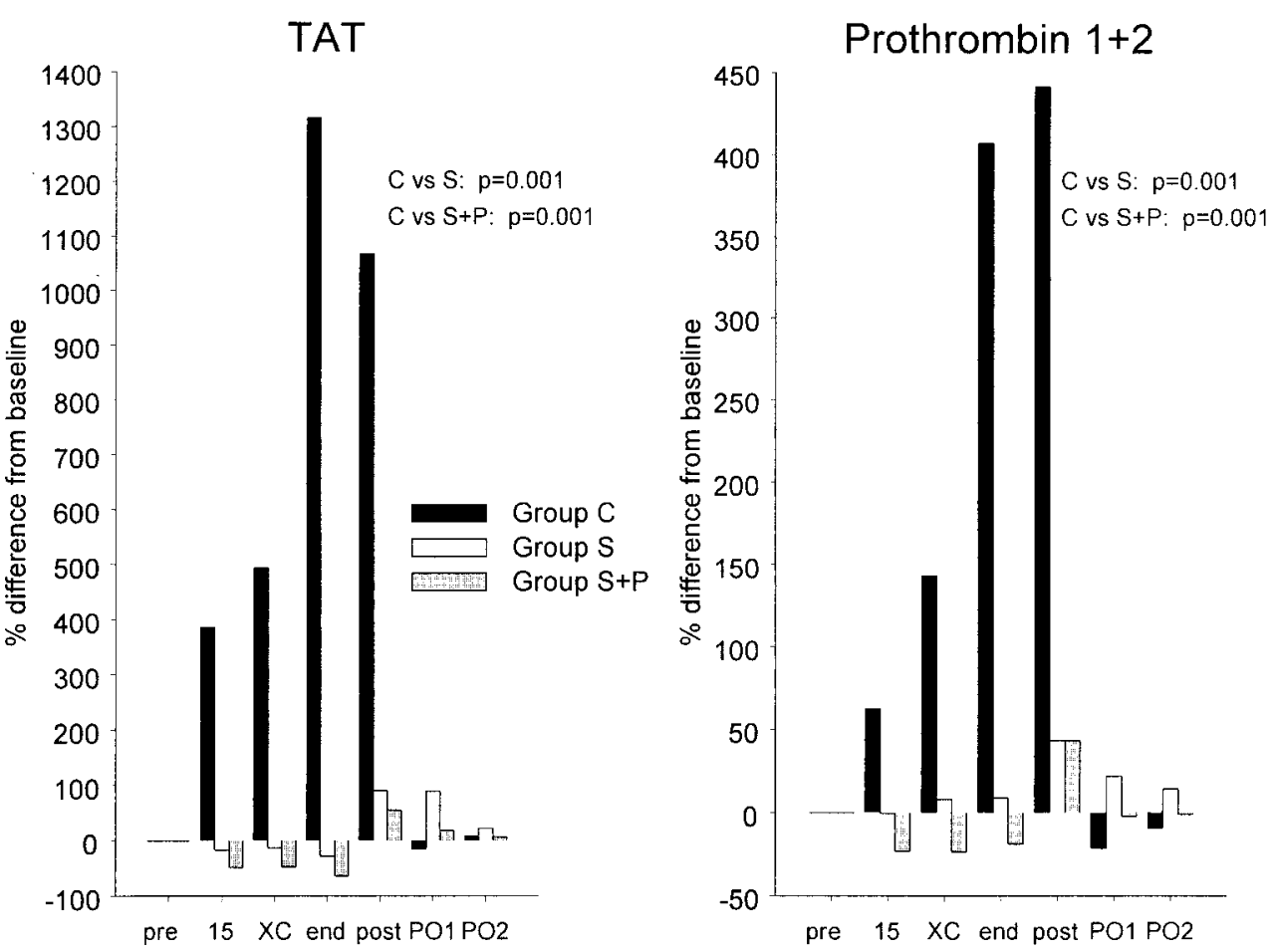

Figure 2. TAT and prothrombin 1+2 levels. Pre, Blood samples taken after induction; P01 and P02, blood samples taken on postoperative days 1 and 2; XC, blood samples taken after release of the aortic crossclamp; end, blood samples taken at the end of CPB; post, blood samples taken 20 minutes after CPB.

was established between levels of TAT and F1+2 $(r=$ $0.916, P<.001$ ) in group $\mathrm{C}$ (Figure 3 ).

\section{Hemolysis}

Free plasma hemoglobin. Whereas mean free plasma hemoglobin levels remain stable in groups $\mathrm{S}$ and $\mathrm{S}+\mathrm{P}$, there is a steady increase from $9.9 \pm 4.3 \mathrm{mg} / \mathrm{dL}$ to $46.6 \pm 17.6$ $\mathrm{mg} / \mathrm{dL}$ at 20 minutes after CPB in group C (Figure 4). Mean total generation of plasma free hemoglobin during the procedure was most pronounced in group C $(353,800 \pm$ $193,475 \mathrm{mg} / \mathrm{dL}$ per procedure) compared with that seen in group $\mathrm{S}(70,140 \pm 56,462 \mathrm{mg} / \mathrm{dL}$ per procedure, $P=.001)$ and group $\mathrm{S}+\mathrm{P}(130,390 \pm 86,308 \mathrm{mg} / \mathrm{dL}$ per procedure, $P=.001)$

Haptoglobin. Mean haptoglobin levels decreased in all groups over time (Figure 4).

\section{Blood Loss and Transfusions}

In group $\mathrm{S}$ an average of $295 \pm 136 \mathrm{~mL}$ and in group $\mathrm{S}+\mathrm{P}$ an average of $370 \pm 172 \mathrm{~mL}(P=$ not significant $)$ of blood was aspirated during CPB and discarded at the end of the procedure. The hematocrit levels on postoperative day 1 were $30.6 \% \pm 4.1 \%$ in group C, $29.9 \% \pm 3.0 \%$ in group $\mathrm{S}$, and $32.8 \% \pm 3.0 \%$ in group $\mathrm{S}+\mathrm{P}(P=.196)$.

The average blood loss during the first 4 hours postoperatively was $210 \pm 80 \mathrm{~mL}(P=.05)$ in group $\mathrm{S}+\mathrm{P}, 326 \pm$
$170 \mathrm{~mL}$ in group $\mathrm{C}$, and $338 \pm 223 \mathrm{~mL}$ in group $\mathrm{S}$. Blood losses between 4 and 8 hours and 8 and 12 hours postoperatively were not statistically significantly different between groups (Figure 5). Dividing the total population into patients who lost more or less than $250 \mathrm{~mL}$ during the first 4 postoperative hours revealed duration of $\mathrm{CPB}(P<.001)$, prolonged crossclamp time $(P=.002)$, and number of bypasses $(P=.03)$ to be incremental risk factors for bleeding. By using the same division with regard to the 3 groups, a significant difference in reduced blood loss was found in favor of group $\mathrm{S}+\mathrm{P}(P=.05$, Table 2$)$.

In none of the groups were blood products given during $\mathrm{CPB}$. In group $\mathrm{S}$ no blood products were given, whereas in group $\mathrm{S}+\mathrm{P} 1$ patient and in group $\mathrm{C} 4$ patients received packed red cells postoperatively $(P=.05)$.

\section{Discussion}

Despite anticoagulation with high doses of heparin during $\mathrm{CPB}$, this procedure is associated with considerable activation of the coagulation system. ${ }^{1}$ The important rise in $\mathrm{F} 1+2$ and TAT levels obtained in our control group confirms the procoagulant effect of CPB. In addition, significant activation of blood platelets and generation of hemolysis was observed. After unclamping, most surgeons reinfuse blood aspirated from the mediastinal and pleural cavities. Recirculation of suction blood is documented to decrease the 


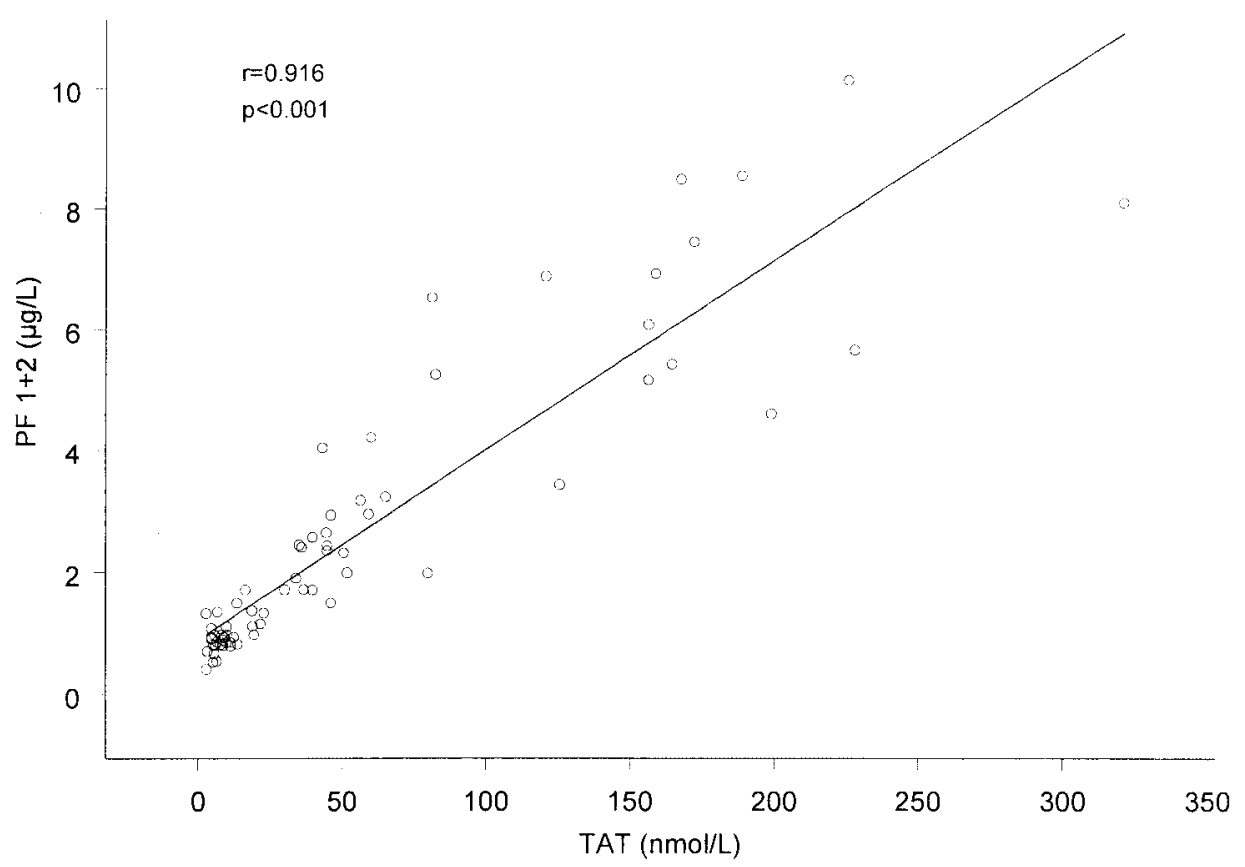

Figure 3. Correlation between TAT and F1+2 in group $C$.

Free plasma haemoglobin

Haptoglobin

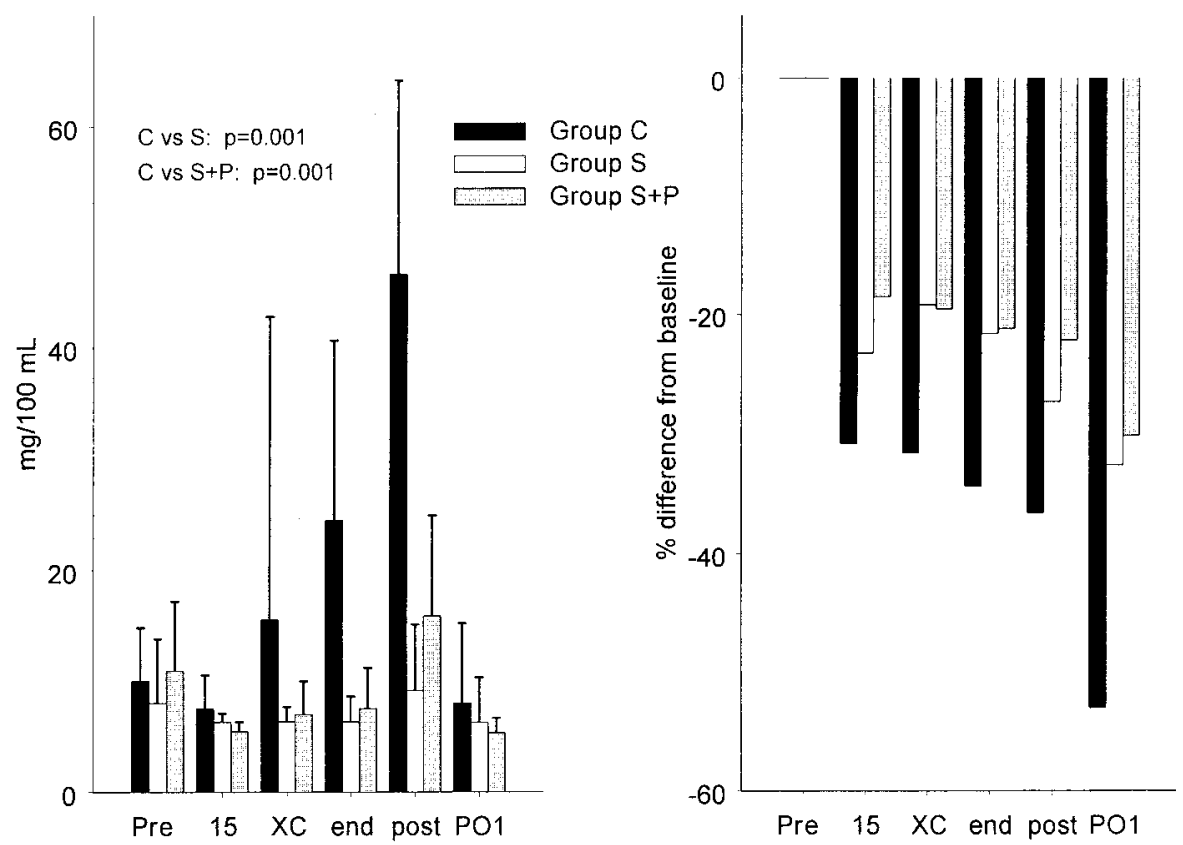

Figure 4. Free plasma hemoglobin and haptoglobin levels. Pre, Blood samples taken after induction; P01 and P02, blood samples taken on postoperative days 1 and 2; XC, blood samples taken after release of the aortic crossclamp; end, blood samples taken at the end of CPB; post, blood samples taken 20 minutes after CPB.

mean arterial pressure, ${ }^{7}$ to activate the coagulation cascade, ${ }^{8,9}$ and to generate hemolysis. ${ }^{8,10}$ As soon as blood comes into contact with tissue factor, the coagulation cascade is activated. ${ }^{11,12}$ As a result of surgical trauma, tissue factor can be present in both mediastinal and pleural cavities. Therefore, blood recuperated from these cavities will be activated, and thrombin will be generated, leading to elevation of both TAT and F1 +2 . In our intervention groups 


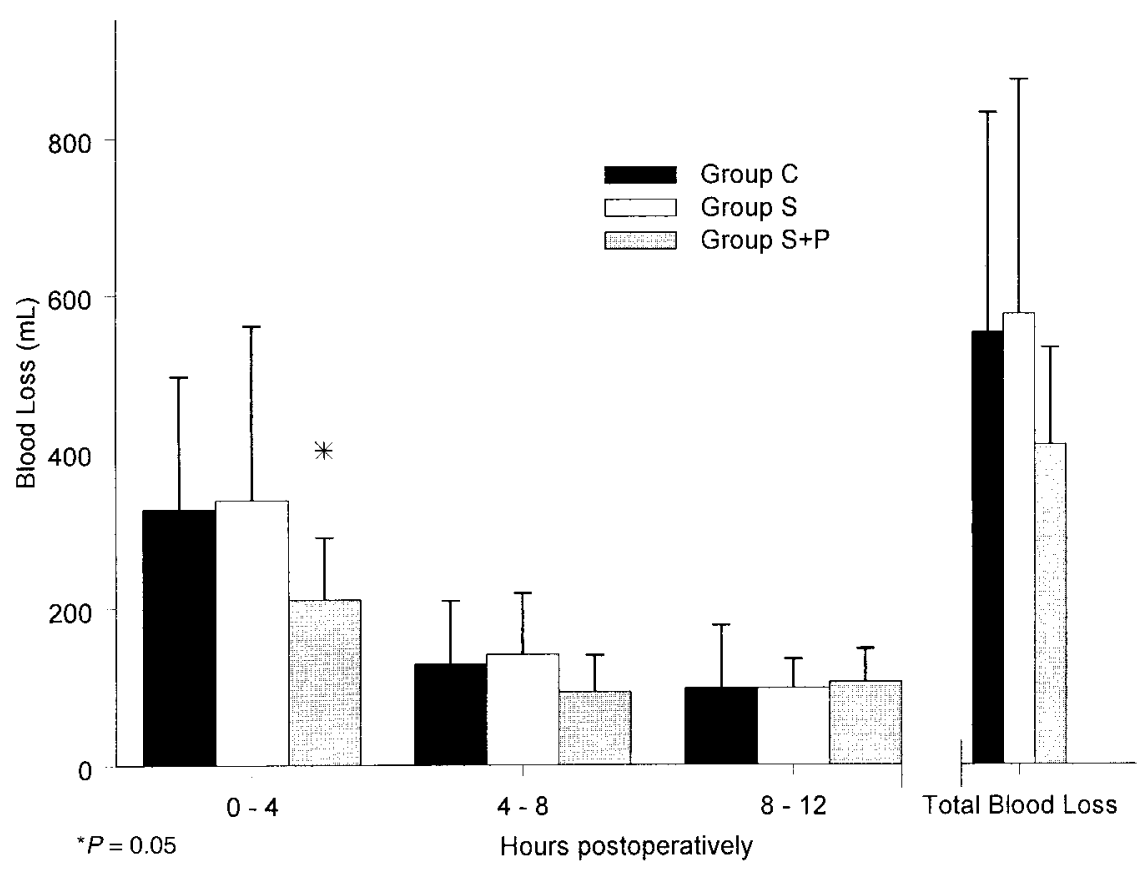

Figure 5. Blood loss.

TABLE 2. Blood loss during the first 4 postoperative hours

\begin{tabular}{lccl}
\hline & $<250 \mathrm{~mL}$ & $>\mathbf{2 5 0} \mathbf{~ m L}$ & Total \\
\hline Group C & 4 & 6 & 10 \\
Group S & 5 & 5 & 10 \\
Group S $+\mathrm{P}$ & 9 & 1 & $10^{*}$ \\
Total & 18 & 12 & 30
\end{tabular}

$* P=.05$.

in which reinfusion of aspirated blood was omitted, almost no rise in TAT and F1+2 levels was observed, clearly suggesting aspirated blood to be the main cause of thrombin generation. A discussion is ongoing whether heparin dosing during CPB on the basis of ACT measurement is optimal or whether heparin by itself is an adequate anticoagulant in this setting. ${ }^{13-15}$ Several studies have shown a poor correlation between ACT and plasma heparin levels, as measured with an anti-Xa method. ${ }^{13}$ However, rapid point-of-care methods to measure heparin levels are still in the process of validation. Therefore, in our study heparin dosing was still adjusted on the basis of the ACT. Despotis and colleagues ${ }^{14}$ described that a more effective suppression of the hemostatic system in CPB may be obtained when heparin dosing is based on heparin blood concentrations rather than on ACT. In their study a negative correlation was found between F1+2 and TAT levels on the one hand and plasma heparin concentrations, as measured with an anti-Xa method, on the other hand. In contrast to this, the study of Knudsen and coworkers ${ }^{15}$ clearly showed that high levels of
F1+2 may be generated during $\mathrm{CPB}$, despite adequate heparin anticoagulation, as measured with a plasma anti-Xa method. In this study suction blood was also reinfused, and the highest F1 +2 levels were similar to those found in our study shortly after unclamping. The high degree of comparability of the F1+2 results of our control group and the results reported by Knudsen and coworkers ${ }^{15}$ makes it unlikely that the low $\mathrm{F} 1+2$ values in patients in whom no aspirated blood was reinfused could be due to higher heparin levels. Differences in the amount of aspirated blood volume may account for the differences found in the literature. However, blood aspirated from cavities covered with endothelium does not activate the coagulation. ${ }^{11}$

Destruction of red blood cells in contact with the pericardium, pleural cavities, or both, was recognized in the early days. ${ }^{16}$ In our control group, free plasma hemoglobin started to increase after the release of the aortic crossclamp simultaneously with a steady decrease in haptoglobin levels over time. In a recent study in which aspirated blood was kept separated until the end of CPB, a similar increase in hemolysis was noticed after reinfusion of this aspirated blood. ${ }^{10}$ Major hemolysis is caused by blood aspirated from nonvascular cavities. This is most likely caused by shear forces, negative pressure, and the blood-air interaction. The effect of mechanical destruction (arterial roller pump) is partially neutralized by means of rapid elimination of the haptoglobin-hemopexin complexes at specific hepatic receptors. Hemolysis generation by means of the arterial roller pump remains negligible during short-term cardiac surgery 
and was confirmed by low free plasma hemoglobin values during $\mathrm{CPB}$ in both retainment groups.

In addition to high circulating levels of heparin, attempts have been made to control activation of the coagulation system by coating the foreign surface area of the CPB. However, generation of TAT and F1+2 in most studies was not conclusive. ${ }^{3}$

Phosphorylcholine coating mimics the characteristic feature of biologic membranes. In vitro experiments, in which various phospholipid coatings were applied to surfaces, showed a very high procoagulant activity of negatively charged phospholipids. This is in contrast to the absence of activation of phosphorylcholine-containing surfaces in coagulation tests. ${ }^{17,18}$ Blood platelets are not only essential for coagulation but also interfere with white blood cell and complement activation. Platelets were activated predominantly in group $\mathrm{C}$ by means of reinfusion of damaged and activated platelets with aspirated blood. However, also in group $\mathrm{S}$, moderate platelet activation is noticed over time, whereas absolutely no increase is observed in group $\mathrm{S}+\mathrm{P}$. Better platelet preservation in group $\mathrm{S}+\mathrm{P}$ is also reflected by lower blood loss in the immediate postoperative period. The difference between group $\mathrm{S}$ and group $\mathrm{S}+\mathrm{P}$ can be seen as the representation of the damage caused by contact with untreated foreign material. This finding is in agreement with previous observations. $^{2}$

No statistical differences regarding duration of $\mathrm{CPB}$, crossclamp time, and number of bypasses were observed between groups. Nevertheless, a significantly higher number of patients lost less than $250 \mathrm{~mL}$ of blood in group $\mathrm{S}+\mathrm{P}$. In the population who lost more than $250 \mathrm{~mL}$ during the first 4 postoperative hours, there was a positive correlation with the duration of $\mathrm{CPB}$, crossclamp time, and number of bypasses, which is in agreement with previous findings. ${ }^{19}$

Development of a dedicated venous reservoir makes it possible to separate aspirated blood coming from different sources. Blood from vascular structures can be safely returned into the circulation, whereas highly activated blood caused by contact with tissue factor should be kept separated. Depending on the amount of blood loss, the latter can be processed with a cell salvage system or discarded. Moreover, recent in vitro research also points out that generation of fat emboli is negligible in groups without recuperation of the mediastinal blood compared with that in a control group. ${ }^{20}$

\section{General Conclusion}

Retainment of blood aspirated out of nonvascular structures will significantly reduce morbidity of CPB. Blood activated by means of tissue factor should be discarded or processed with a cell salvage system. Phosphorylcholine coating is not a main participant for control of the procoagulant effect of $\mathrm{CPB}$ but results in decreased platelet activation and decreased blood loss.

\section{Limitations of the Study}

Because our study concerns a biologic system with relatively large SDs in a limited number of patients, our data should be interpreted with caution. Large randomized studies are necessary to investigate the influence of reinfusion of aspirated blood on morbidity.

We thank Sorin-Biomedica, Mirandola, Italy, for providing the phosphorylcholine-coated oxygenators, cannulas, and custom packs.

\section{References}

1. Tanaka T, Takao M, Yada I, Yuasa H, Kugasawa M, Degushi K. Alterations in coagulation and fibrinolysis associated with cardiopulmonary bypass during open heart surgery. J Cardiothorac Anesth. 1989;3:181-8

2. De Somer F, François K, van Oeveren W, et al. Phosphorylcholine coating of extracorporeal circuits provides natural protection against blood activation by the material surface. Eur J Cardiothorac Surg. 2000;18:602-6.

3. Wendel HP, Ziemer G. Coating-techniques to improve the hemocompatibility of artificial devices used for extracorporeal circulation. Eur J Cardiothorac Surg. 1999;16:342-50.

4. Malinauskas RA, Sade RM, Dearing JP, Spinale FG, Crawford FA, von Recum AF. Blood damaging effects in cardiotomy suction return. J Extracorporeal Tech. 1988;20:41-6.

5. Fink PC, Römer M, Haeckel R, Fateh-Moghadam A, Delanghe J, Gressner AM, et al. Measurement of proteins with the Behring Nephelometer: a multicentre evaluation. J Clin Chem Clin Biochem. 1989; 27:261-76.

6. Johnson AMA. A new international reference preparation for proteins in human serum. Arch Pathol Lab Med. 1993;117:29-31.

7. Lavee J, Naveh N, Dinbar I, Shinfield A, Goor DA. Prostacycline and prostaglandin $\mathrm{E}_{2}$ mediate reduction of increased mean arterial pressure during cardiopulmonary bypass by aspiration of shed pulmonary venous blood. J Thorac Cardiovasc Surg. 1990;100:546-51.

8. de Haan J, Boonstra PW, Monnink SHJ, Ebels T, van Oeveren W. Retransfusion of suctioned blood during cardiopulmonary bypass impairs hemostasis. Ann Thorac Surg. 1995;59:901-7.

9. Walpoth BH, Eggensperger N, Hauser SP, Neidhart P, Kurt G, Spaeth $\mathrm{PJ}$, et al. Effects of unprocessed and processed cardiopulmonary bypass blood retransfused into patients after cardiac surgery. Int J Artif Organs. 1999;22:210-6.

10. Hansbro SD, Sharpe DAC, Catchpole R, Welsh KR, Munsch CM, McGoldrick JP, et al. Hemolysis during cardiopulmonary bypass: an in vivo comparison of standard roller pumps, nonocclusive roller pumps and centrifugal pumps. Perfusion. 1999;14:3-10.

11. Boisclair MD, Lane DA, Philippou H, Esnouf MP, Sheikh S, Hunt B, et al. Mechanisms of thrombin generation during surgery and cardiopulmonary bypass. Blood. 1993;82:3350-7.

12. Morris KN, Kinross FM, Stirling GR. Hemolysis of blood in the pericardium: the major source of plasma hemoglobin during total body perfusion. J Thorac Cardiovasc Surg. 1965;49:250-8.

13. Niles SD, Sutton RG, Ploessl J, Pennell B. Correlation of ACT as measured with three commercially available devices with circulating heparin level during cardiac surgery. J Extracorporeal Technol. 1995; 27:197-200.

14. Despotis GJ, Joist JH, Hogue CW Jr, Alsoufiev A, Joiner-Maier D, Santoro SA, et al. More effective suppression of hemostatic system activation in patients undergoing cardiac surgery by heparin dosing based on heparin blood concentrations rather than ACT. Thromb Haemost. 1996;76:902-8.

15. Knudsen L, Hasenkam JM, Kure HH, Hughes P, Bellaiche L, Ahlburg $\mathrm{P}$, et al. Monitoring thrombin generation with prothrombin fragment 1.2 assay during cardiopulmonary bypass surgery. Thromb Res. 1996; $84: 45-54$. 
16. Boisclair MD, Lane DA, Philippou H, Sheikh S, Hunt B. Thrombin production, inactivation and expression during open heart surgery measured by assays for activation fragments including a new ELISA for prothrombin fragment F1+2. Thromb Haemost. 1993;70:253-8.

17. Zwaal RFA, Hemker HC. Blood cell membranes and haemostasis. Haemostasis. 1982;11:12-39.

18. Yianni YP. Biocompatible surfaces based upon biomembrane mimicry. In: Quinn PJ, Cherry RJ, editors. Structural and dynamic prop- erties of lipids and membranes. London: Portland Press Ltd; 1992. p. $182-217$.

19. Tuman KJ, McCarthy RJ, O'Connor CJ, McCarthy WE, Ivankovitch AD. Aspirin does not increase allogeneic blood transfusions in reoperative coronary artery surgery. Anesth Analg. 1996;83:1178-84.

20. Brooker RF, Brown WR, Moody DM, Hammon JW Jr, Reboussin DM Deal DD, et al. Cardiotomy suction: a major source of brain lipid emboli during cardiopulmonary bypass. Ann Thorac Surg. 1998;65:1651-5.

\section{Notice from the American Board of Thoracic Surgery regarding trainees and candidates for certification who are called to military service related to the war on terrorism}

The Board appreciates the concern of those who have received emergency call to military service. They may be assured that the Board will exercise the same sympathetic consideration as was given to candidates, in recognition of their special contributions to their country, during the Viet Nam conflict and the Persian Gulf conflict with regard to applications, examinations, and interruption of training. If you have any questions about how this might affect you, please call the Board office at 847-475-1520.

Peter C. Pairolero, MD

The American Board of Thoracic Surgery 